BNL 51003

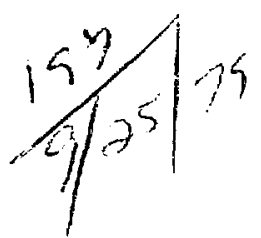

\title{
EXTERNAL EXPOSURE MEASUREMENTS AT BIKINI ATOLL
}

\author{
N.A. GReENHOUSE, R.P. Miltenberger, AND E.T. Lessard
}

MASTER

January 1979

BROOKHAVEN NATIONAL LABORATORY

ASSOCIATED UNIVERSITIES, INC.

UNDER CONTRACT NO. EY-76-C-02-0016 WITH THE

UNITED STATES DEPARTMENT OF ENERGY 


\title{
EXTERNAL EXPOSURE MEASUREMENTS AT BIKINI ATOLL
}

\author{
N.A. Greenhouse, R.P. Miltenberger, and E.T. Lessard
}

January 1979

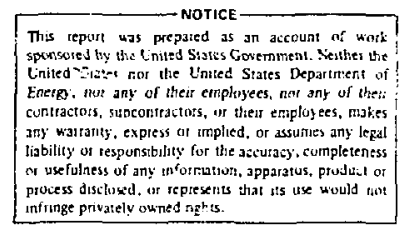

BROOKHAVEN NATIONAL LABORATORY UPTON, NEW YORK 11973 


\section{ABSTRACT}

External exposure rate surveys from 1975 to 1977 on the islands Nam, Eneu and Bikini of Bikini Atoll gave average external exposure rates of $24,5.7$ and $32 \mu \mathrm{R} / \mathrm{hr}$ respectively. The exposure rate on Eneu Island is uniform, whereas those on Bikini and Nam range from 7.0 to $80 . \mu \mathrm{R} / \mathrm{hr}$. Based on an assumed living pattern at Bikini Island, the adult male Bikinian is estimated to be in the prestence of an external radiation field corresponding to $16 \mu \mathrm{R} / \mathrm{hr}$ due to debris and fallout from the 1954 BRAVo incident. This corresponds to a 30 year dose equivislent of 2.8 rem. 


\section{INTRODUCTION}

In April 1975, Brookhaven National Laboratory initiated an external survey of Bikini Atoll in order to obtain information concerning the ambient external radiation levels resulting from the mid 1950's weapons testing program and to make dose equivalent commitment determinations for the individuals living in the surveyed area. From 1975 to 1977, measurements were made to provide sufficient information on the external exposure received by the Marshallese people.

Most of the information concerning Bikini and Eneu Islands was obtained in Apri1 1975, when environmental ionization chamber measurements were made. In addition, thermoluminescent dosimeters (TLDs) were placed in the field and exposed for six moriths at Bikini Island to verify the uniformity of the exposure. other groups assisted in these surveys. The team from Lawrence Livermore Laboratory (UCRL) made a detailed survey of Bikini and Eneu Islands in June 19754,9, and they refer to the information presented in this report as BNL unpublished data. In general, their results are substantiated by the exposure and dose equivalent cormitments calculated here.

The equipment used in 1975 consisted of a Reuter Stokes environmenta1 radiation monitor model RSS-111 and a Baird-Atomic scintillation detector consisting of a sodium iodide detector $(2.5 \mathrm{~cm}$ in diameter by $3.9 \mathrm{~cm}$ in length) connected to a ratemeter readout. Portable survey meters were used to help locate gross changes in the external exposure rate. Lithium fluoride thermoluminescent dosimeters were left on Bikini Island and retrieved in December 1975.

Environmental exposure levels were assessed via the RSS-111 and a NaI gamma spectrometer whose purpose was to determine the photon energy distribution and to compensate for the nonlinearity in the RSS-111 instrument response.

This report presents all of the external exposure data collected to date for Bikini Atoll by BNL. These data have been used to make external exposure estimates for the people living on Bikini Island, and the BNL data have teen compared with UCRL data ${ }^{9}$ for Bikini Atoll.

\section{INSTRUMENTATION AIND METHODS}

\section{A) Ion Chamber Measurements}

All environmental exposure rate measurements were obtained with a Reuter Stokes environmental radiation monitor model RSS-111, which is designed to measure environmental radiation as low as $100 \mu \mathrm{R} / \mathrm{yr}$. The RSS-111 consists of a spherical high pressure ion chamber filled with argon to a pressure of 25 atm. Incident radiation produces ion pairs within the active volume of the chamber which result in an ionization current. The current flow is measured by an electrometer and is directly related to the free air ionization rate ${ }^{8}$.

The active volume of the stainless steel ionization charuber is known to $\pm 1 \%$. The ionization current produced in the chamber is a function of incident radiation from an external field, cosmic-ray response, and contamination present 
in the stainless steel. The instrument response is energy dependent, and data from the manufacturer indicate an error of as much as 6 to $10 \%$ could result if energy corrections are not made to the gross readings ${ }^{8}$.

The RSS-11ls used in this study were calibrated at the factory against radium sources whose calibration is traceable to the National Bureau of Standards. The calibration of the instruments was also checked at the Environmental Monitoring Laboratory (formerly Health and Safety Laboratory) before and after field use.

In $V^{\prime}$ ? report on external exposure for all other atolls surveyed by $\mathrm{BNL}^{3}$, energy dependence corrections were calculated for data from Rongelap and Rongerik Atolls. The factors needed to compensate the RSS-111 resoonse for energy dependence ranged from 1.01 to 1.05 . The mean correction was approximately 1.02 .

\section{B) Thermoluminescent Survey}

Lithium fluoride (LiF) thermoluminescent dosimeter chips 1/4-inch square were used ${ }^{5}$, for several reasons. I,j.F is approximately a tissue equivalent material, and its response is essentially energy independent for photon energies greater than $20 \mathrm{keV}$ up to several MeV. The system is precise to $\pm 2 \%$ and has a long term retention of $5 \%$ loss at room temperature for one year. These qualities made the IiF ideal for use in the Marshall Islands.

A11 TLDs were cleaned with analytical grade methanol before departure for the Marshall Islands and prior to analysis. Prior to irradiation, the TLDs were annealed at $400^{\circ} \mathrm{C}$ for one hour and them at $100^{\circ} \mathrm{C}$ for $2 \mathrm{hr}$. After field exposure and before reading, the TLDs were annealed at $100^{\circ} \mathrm{C}$ for $10 \mathrm{~min}$.

In addition to the TLDs exposed in the field at Bikini and Eneu, several sets of TLDs were assembled for use in correcting field measurements for background, fading and air transportation contributions. Several TLDs were annealed and then inmediately stored in a lead pig in the BNL analytical counting area. An equal number of TLDs were irradiated to $100 \mathrm{mR}$ and stored with the background TLDs to determine fading losses. Four other TLDs were sent to Kwajalein and stored there in a lead pig to determine in-transit contributions to the response. All TLD results have been corrected for these parameters.

The TLDs were calibrated at BNL with $137 \mathrm{Cs}$ gamma and $90 \mathrm{Sr} / 90 \mathrm{Y}$ betas. Results are directly related to the external exposure and beta absorbed dose that would be received by individuals Iiving on Bikini and Eneu Islands.

Because the total response must be differentiated into beta and gamma components, a TLD holder was developed that would eliminate nearly $100 \%$ of the $90_{Y}$ beta of $2.27 \mathrm{MeV}$ (Figure 1). Four TLDs are used per holder. Two are covered by $1100 \mathrm{mg} / \mathrm{cm}^{2}$ of aluminum and Mylar which is of sufficient mass density thickness to eliminate beta response; these provide the gamma response. The two other TLDs are shie1ted by $\sim 15 \mathrm{mg} / \mathrm{cm}^{2} \mathrm{Mylar}$ to respond to the total gamma-beta contribution at one meter above the earth's surface. The difference between the 
responses of the two TLD sets gives the beta response. TLDs placed in the field were positioned with the open windows facing the soil.

Berause shielding part of the dosimeter may bias the data, an attempt was made to predict the resulting error by randomly placing four of the dosimeters (16 TLDs) together, open windows facing the soil, in a series of tests using ${ }^{90} \mathrm{Sr}-90 \mathrm{Y}$ as a source, placed $30 \mathrm{~cm}$ from the TLDs. The open and closed windows were varied to cover all combinations of field positioning. The error using a point source and a source-to-detector distance of $30 \mathrm{~cm}$ was $<2.5 \%$. Because the field situation represents a distributed plane source, and the source-tom dosimeter distance was between 50 and $100 \mathrm{~cm}$, the field situation shouid have a minimal positioning error associated with the results (Eigure 2).

\section{RESULTS}

A total of 203 RSS-11l measurements were made on Bikini Atoll. Each data point is the average of at least 20 individual readings. This assures the precision of the value, and the initial calibration guarancees accuracy. The mean exposure rate is reported with one standard deviation calculated by assuming that the data obtained from a specific site follow a Gaussian distribution.

Tables 1 through 5 represent all data taken on Bikini Atoll. Table 2 1 ists the data from Nam Island, locatcd at the northwest corner of tine atoll, closest to ground zero of the BRAVO device. The average external exposure rate over the iand areas monitored is $s 24 \mu \mathrm{R} / \mathrm{hr}$. This is six times nigher than the background levels at Wotje, Ailuk or Uririk Ato $1 \mathbf{s}^{3}$. This average value should not be interpreted as a true value for the Nam island average, since ciense vegetation prevenced a representative sample of readings over the whole island. Nam is uninhabited at present and is not used for food production. The exposure rate is non-uniform and varies significantly as a function of location.

Table 3 presents the data from Eneu Isiand, located soath and west of Bikini Island. Eneu received the least fallout contanination as evinced from the average external radiation exposure rate of $5.7, \mu \mathrm{R} / \mathrm{hr}$. This value is 1.5 tines the natural background and is the lowest external exposure rate on any of the islands surveyed. Figure 3 shows the sample sites and the exposure rate measured at each site. These data demonsirate the uniforaity of exposure rate on this island.

The external exposure rate on Bikini Island is a strong function of location (Figure 4A-E). It is the lowest in the areas, closest to the lagoon and current housing*, highest in the center of the island and intermediate in other areas. The average, exposure rate for the $i s l$ end, based on an average of ali the data $i$ s $32.1 \mu \mathrm{R} / \mathrm{hr}$. Table 4 iists exposure rate measurements made in the living areas of the available housing. Table 5 lists all other exposure rate measurements made at Bikini Island.

* In 1978, the Department of Interior made the decision to reiocate the inhabitants of Bikini Atoll to either Ejit Island, Majuro Atoll, or Kili Island. The relocation took place in August 1978. 
The TLD data for Bikini Island ('Table i) agree with the RSS-111 measurements, but no constant relationship is seen between beta dose and gamma exposure. Non-uniform deposition of fallout material in the areas surveyed and translocation of material are major factors governing this result.

\section{DISCUSSION OF RESULTS}

The average exposure rate as measured for each island is 1isted in Table 6. Estimation of the dose equivalent for the inhabitants of Bikini Atoll is debatable due to the nonuniform distribution of radioactive material within given areas of the atoil. The exposure rates measured on Eneu Island are fairly uniform, but those on Bikini Island showed significant differences between areas (Table 5 along with Figure 4A-4E). In the UCRL work ${ }^{4}$, this problem was approached and a solution derived by estimating the fractions of an individual's time spent in various areas. These estimates 4 are used here (Table 7) to construct external exposure rate estimates for the various activities based on the measurements reported in Tables 2 through 5 . The exposure rate for the lagoon was obtained by assuming that it would be less than or equal to that in the areas of continual habitation. The values for other islands were obtained by assuming that the Marshallese would spend an equal amount of time on each of the other islands surveyed. All other estimates were made by taking the average of all measurements made within the area of interest.

Table 8 shows the estimated exposure rate for each pattern of activity in Table 7 based on continuous occupancy of Bikini Atoll. Table 9 shows the estimated exposure rate for each age group as weighted by the percent of time spent in each area, for inhabitants of Bikini Atoll. Sumation of the exposure rates in all the areas provides the average tota1-body exposure rate for each age group.

Using the average hourly exposure rate, the long term external dose equivalent was calculated (Table 10). The data were corrected for background (terrestrial and cosmic. radiation) by using the average exposure rate on Wotje and Ailuk as representative samples of the normal Marshall Island environment ${ }^{3}$. These data for Bikini residents are lower than UCRL data 9 for living patterns 2 and 3 , which give the estimated integral external gama dose equivalent for 30 years as 4 rem, because the present estimates include the measured exposure rate for habitation of the newly constructed housing. These indoor values are $39 \%$ lower than those previously reported and their use reduces the total estimated reduction in the 30 year dose equivalent commitment by $32 \%$.

The ICRP suggests 6 that population groups should not receive a 30 -year dose equivalent of more than 5.0 rem to the whole body from sources other than medical equipment or natural background. For the external radiation component at Bikini Atoll, this requirement is met; the problem is that external radiation is not the sole source of radiation exposure to the Marshallese. The dietary pathway, based on UCRL data, could increase the 30 -year total body dose equivalent commitment by a factor of 4 .

Whole-body counting data taken in $1974^{1}, 1977^{2}$ and $1978^{7}$ indicate that the dietary pathway became the prime source of radiation exposure after January 
1977. Current in vivo data indicate that the equilibrium body burdens for $137 \mathrm{Cs}$ will range from $3 \overline{\mu C i}$ to $30 \mu \mathrm{Ci}$ in the Bikini population. This corresponds to a 30-year internal dose equivalent that falls in the range of 11 to 110 rem. Bioassay data obtained from Bikinians during 1978 indicate that bone marrow dose equivalents for 30 years of habitation would be between 0.4 and 1.0 rem from $90 \mathrm{Sr}^{-90 \mathrm{Y}} 10$.

Reviewing the Bikini dose commitment in this 1ight, one immediately realizes that the inhabitarts would receive a total body dose equivalent exceeding the ICRP criteria ${ }^{6}$. Thus, for Bikini Atoll, we concur with the UCRL recommendation ${ }^{9}$ that more must be done to lower the total body and bone marrow radiation exposures so that the Marshailese can live within the population dose equivalent recomendations. 


\section{ACKNOWLEDGEMENTS}

The field portion of the radiological survey of the Marshall Islands was accomplished by a very intense and thorough effort by people representing different organizations. The number of samples collectei and the amount of information obtained during each survey was a direct result of the cooperation and diligent effort of the following individuals:

Owen H. Davis

Francis J. Haughey

Kim S. Kastens

Alan V. Kuehner

Janakiram R. Naidu

Victor A. Nelson

Margaret A. Reilly

Michael S. Terpilak

Richard D. Williams
Pacific Gas and Electric Company

Rutgers University

Marine Science Center, SUNY at Stony Brook

Brookhaven National Laboratory

Brookhaven Nationa1 Laboratory

University of Washington, LRE

State of Pennsylvania, Bureau of Radiological Health

DHEW, Bureau of Radiological Health

Medi-Physics, California

We are also deeply indebted to the following BNL personnel who complemented the field work by performing TLD analyses on the numerous samples that were collected and by pretesting all equipment prior to use in the field:

Joseph Balsamo

James Gilmartin

George Hughes

Leigh Phillips

Francis Stepnoski

The survey crew extends its thanks to the Nevada Operations Office and Pacific Area Support Office for support services that resulted in a smooth and $e \hat{-}-$ ficient survey. Support from the Kwajalein Missile Range and the site contractor, Global Associates, and from the crew of the R. V. Liktanur is great 1 y appreciated.

The outstanding cooperation of personnel from the Trust Territory of the Pacific Islands and from the Office of the District Administrator of the Marshall Islands, as well as that of the Bikini people, played an important part in the successful completion of the survey. 


\section{REFERENCES}

1. R. A. Conard et al, A Twenty Year Review of Medical Findings in a Marshallese Population Accidentally Exposed to Radioactive Fallout, BNL 50424,1975 .

2. S. Cohn, Medical Department, BNL, Personal Communication. National Laboratory (Upton, New York 11973).

3. N. A. Greenhouse and R. P. Miltenberger, External Exposure Survey and Dose Predictions For Rongelap, Rongerik, Ailuk, and Wotje Atolls, BNL 50797 , 1977.

4. P. H. Gudiksen, T. R. Crites, and W. L. Robison, External Dose Estimates for Future Bikini Atoll Inhabitants, Lawrence Livermore Laboratory, UCRL51879 Rev. 1, 1976 .

5. TLD Materials and Systems, Harshaw Chemical Company, Solon, Ohio, undated.

6. Recommendations of the International Commission on Radiological Protection, ICRP Pub1. 9, (Pergamon, New York, 1965.

7. R.P. Milterberger, N.A. Greenhouse and E.T. Lessard, whole-Body Counting Results from 1974 to 1979 for Bikini Island Residents, submitted to Health Physics, 1979.

8. Environmenta1 Radiation Monitor Model RSS-111 Operational Manual, Reuter Stokes Instruments, Inc., Cleveland, Ohio, undated.

9. W. L. Robison, W. A. Phillips and C. S. Colsher, Dose Assessment at Bikini Ato11, Lawrence Livermore Laboratory, UCRL-51879 Part 5, 1977.

10. N. A. Greenhouse, R. P. Miltenberger, E. T. Lessard, Dosimetric Results For the Bikini Population, Submitted to Health Physics, 1979. 
Table 1

Bikini Island TLD Exposure Survey (129 days), Dec. 7, 1974, to Apr. 15, 1975

\begin{tabular}{|c|c|c|}
\hline \multirow[b]{2}{*}{ Location } & \multicolumn{2}{|c|}{ Total } \\
\hline & $\begin{array}{c}\gamma \text { Exposure } \\
\mu R\end{array}$ & $\begin{array}{c}\beta \text { Dose, } \\
\mu \mathrm{rad}\end{array}$ \\
\hline House 4 - inside & $28400 *$ & - \\
\hline House 4 - ouiside 20 in. above ground & $36200 *$ & - \\
\hline House 20 - inside & $29900 *$ & - \\
\hline House 20 - outside mid backyard & $27800 *$ & - \\
\hline House 38 - inside & $48600 *$ & - \\
\hline House 38 - outside mid backyard & $41000 *$ & - \\
\hline Big twin coconut trees, west side of tree near USGS well & $194300 *$ & - \\
\hline Behind house 40 , cookhouse at 18 in. off ground & 26800 & 1500 \\
\hline Behind house 35 , behind living area at 22 in. off ground & 45300 & 25800 \\
\hline Behind house 30 , behind living area at 20 in. off ground & 32800 & 10300 \\
\hline East/west road by house 30 about 30 yd. north of bunker & 35600 & 11000 \\
\hline Behind house 25 near banana and papaya patch, 22 in. off ground & 54000 & 29800 \\
\hline Behind house 21,20 in. off ground & 26300 & 14700 \\
\hline Behind house 15 & 29900 & 4700 \\
\hline Behind house 10 & 73000 & 62800 \\
\hline Behind house 6 & 36200 & 8400 \\
\hline By USGS well and twin coconut trees & 79100 & 85100 \\
\hline Control 1 & 2900 & 2400 \\
\hline Control 2 & 5100 & 0 \\
\hline Control 3 & 6300 & 0 \\
\hline
\end{tabular}

*Total unshielded response.

Table 2

Nam Island, Bikini Ato11, RSs-111 Exposure Survey, April 1976

Location

$\mu \mathrm{R} / \mathrm{hr}$

West Transect - 200 meters from soil pit

$33.4 \pm 0.6$

West Transect - 100 meters from soil pit

$16.7 \pm 0.4$

East Transect - 200 meters from soil pit

$17.6 \pm 0.5$

East Transect - 100 meters from soil pit

$15.2 \pm 0.4$

East Transect - 245 meters north of lagoon beach

$44.9 \pm 0.7$

East Transect - 150 meters north of lagoon beach

$23.1 \pm 0.5$ 
rable 3

ENEU ISLAND RSS-111 EXPOSURE SURVEY APRIL 197;

South road to ocean near middle of island

2nd coconut row, ocean side of runway adjacent to marker 4

2nd coconut row, ocean sidi of runway adjacent to marker 1

2nd coconut row, ocean side of runway adjacent to marker 2

2nd coconut row, ocean side of runway adjacent to marker 3

lst coconut row, ocean side of runway adjacent to marker 1

Midway north of runway apron and coconut row

5th coconut row up the road from north corner of runway apron

16 th coconut row by 2 nd large nature tour

Group of old buildings, south of church, ocean side of road

West bend in road just north of old church, ocean side

North $1 / 3$ way up road to Camp Blandy, ocean side

North $2 / 3$ way up road to Camp Blandy, ocean side

81 andy area just, south of soil pit 3, 100 yd from lagoon beach

Blandy area just south of soil pit 3, $100 \mathrm{gd}$ from ocean beach

North end of Camp Blandy near middle of the is land

North end of Camp Blandy near lagoon road, ocean side

Lagoon road south of Camp Blandy, $100 \mathrm{yd}$ west of church

Lagoon road about 150 yd north of Camp Blandy

Bunker near dock

old bldg. frame work due west of runway marker 1
$7.2 \pm 0.52$

$5.6 \pm 0.25$

$4.2 \pm 0.17$

$4.9 \pm 0.37$

$8.2 \pm 0.10$

$5.3 \pm 0.16$

$6.1 \pm 0.32$

$8.7 \pm 0.23$

$6.1 \pm 0.14$

$6.9 \pm 0.12$

$8.1 \pm 0.31$

$4.9 \pm 0.30$

$6.5 \pm 0.20$

$6.1 \pm 0.15$

$5.6 \pm 0.31$

$5.9 \pm 0.29$

$6.0 \pm 0.21$

$5.7 \pm 0.15$

$5.0 \pm 0.35$

$5.0 \pm 0.22$

$6.1 \pm 0.27$ 
Table 4

Measured Exposure Rates Within Fermanent Housing Constructed on Bikini Island

\begin{tabular}{|c|c|c|c|}
\hline Location & $\begin{array}{c}\text { Exposure rate } \\
\mu R / h r\end{array}$ & Location & $\begin{array}{c}\text { Exposure rate } \\
\mu R / h r\end{array}$ \\
\hline House 21 & $6.6 \pm 0.13$ & House 4 & $7.5 \pm 0.15$ \\
\hline House 22 & $7.3 \pm 0.37$ & House 6 & $7.8 \pm 0.28$ \\
\hline House 23 & $7.2 \pm 0.10$ & House 7 & $10.5 \pm 0.28$ \\
\hline House 25 & $7.3 \pm 0.28$ & Outside house 7 & \\
\hline Hou se 26 & $7.3 \pm 0.25$ & north side on gravel & $12.9 \pm 0.20$ \\
\hline School & & House 9 & $10.7 \pm 0.16$ \\
\hline middle of the room & $7.2 \pm 0.10$ & House 10 & $11.1 \pm 0.25$ \\
\hline Hou se 30 & $8.4 \pm 0.14$ & House 11 & $9.3 \pm 0.23$ \\
\hline House 31 & $8.9 \pm 0.10$ & Hou se 12 & $9.7 \pm 0.49$ \\
\hline House 32 & $10.0 \pm 0.37$ & House 13 & $13.3 \pm 0.19$ \\
\hline liouse 33 & $9.6 \pm 0.45$ & House 15 & $11.6 \pm 0.23$ \\
\hline House 35 & $15.8 \pm 0.19$ & House 16 & $11.5 \pm 0.60$ \\
\hline House 36 & $13.1 \pm 0.17$ & House 18 & $8.2 \pm 0.17$ \\
\hline House 37 & $11.9 \pm 0.30$ & Hou se 19 & $7.8 \pm 0.26$ \\
\hline House 40 & $11.1 \pm 0.15$ & House 20 & $7.2 \pm 0.13$ \\
\hline
\end{tabular}


Table 5

Bikini Island KSS-111 Exposure Survey, April 1975

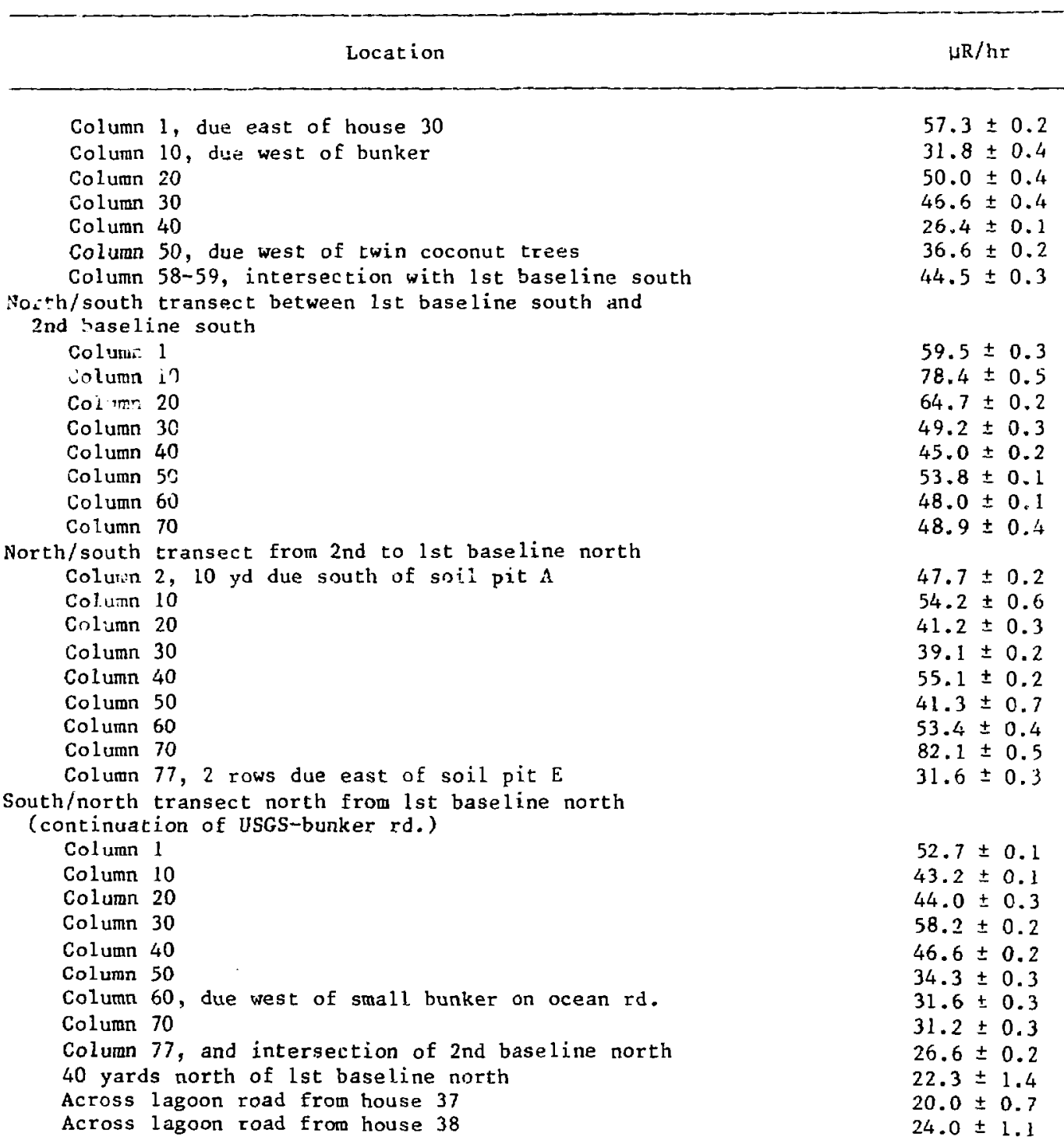


Table 5 (Cont'd)

Bikini Island RSS-Ill Exposure Survey, April 1975

Across lagoon road itron house 39

$22.9 \pm 0.6$

10 columns north of house 40

South on ocean beach road from 2 nd baseline north

Cosumn 1

Columin 10

Column 20, 3 columns south of small bunker

Colum 30, 3 rows east of ocean beach road

Column 40, 6 rows east of ocean beach road

column 50, 1 row in from ocean beach road

Column 60,3 rows in from ocean beach road

$28.5 \pm 0.6$

Column 70, 1 row in from ocean beach road

Column 78, at intersection of ocean beach road and

lst baseline north

North/south transect along road separating (1972 designation

of rows) rows 24 \& 25 from center baseline to lst baseline north

Column 1

a

Column 10

$23.6 \pm 1.0$

$38.3 \pm 1.3$

$25.9 \pm 0.4$

$22.4 \pm 1.1$

$49.4 \pm 0.8$

$33.4 \pm 0.4$

$33.4 \pm 0.3$

$37.0 \pm 0.7$

Column 20

Column 30

Column 40

Column 49 and the intersection of 1 st baseline north

$33.2 \pm 0.5$

North/south transect along breadfruit row starting at 2nd baseline north

Column 4 of older plantings behind house 40

Breadfruit planting east of house 39

Breadfruit planting east of horse 38

Breadfruit planting near small bunker between houses $37 \& 38$

Breadfruit east of house 37

2 columns of coconut trees north of lst baseline north

lst breadfruit south of lst baseline north by soil pit $D$

5 th breadfruit east of house 36

9th breadfruit near banana garden, house 35

12 th breadfruit east of Japanese memorial and house 34

15 th breadfruit north of center baseline and east of house 31

$22.6 \pm 0.3$

$62.0 \pm 0.2$

$26.7 \pm 0.4$

$52.9 \pm 1.1$

$42.6 \pm 0.3$

$48.0 \pm 0.3$

$49.2 \pm 0.9$

$59.0 \pm 0.4$

$40.9 \pm 0.5$

$29.9 \pm 0.5$

$28.0 \pm 0.8$

$23.0 \pm 0.3$

$42.0 \pm 0.7$

$33.1 \pm 0.6$

$34.1 \pm 0.6$

$38.8 \pm 0.3$

$22.4 \pm 0.2$

North/south transect along breadfruit row from center baseline

Due east and house 30

Breadfruit near house 26 and 30 yards east of papaya patch

Breadfruit 8 near bouse 4 and main garden

$18.4 \pm 0.2$

$26.2 \pm 0.3$

Due east of houses 20 and 21

$48.4 \pm 0.5$

$19.2 \pm 0.3$

Due east of house 17

$25.6 \pm 0.5$

Due east of house 16

just north of center baseline and soil pit

$30.3 \pm 0.2$ 
Table 5 (Cont'd)

Bikini Island RSS-111 Exposure Survey, Apri1 1975

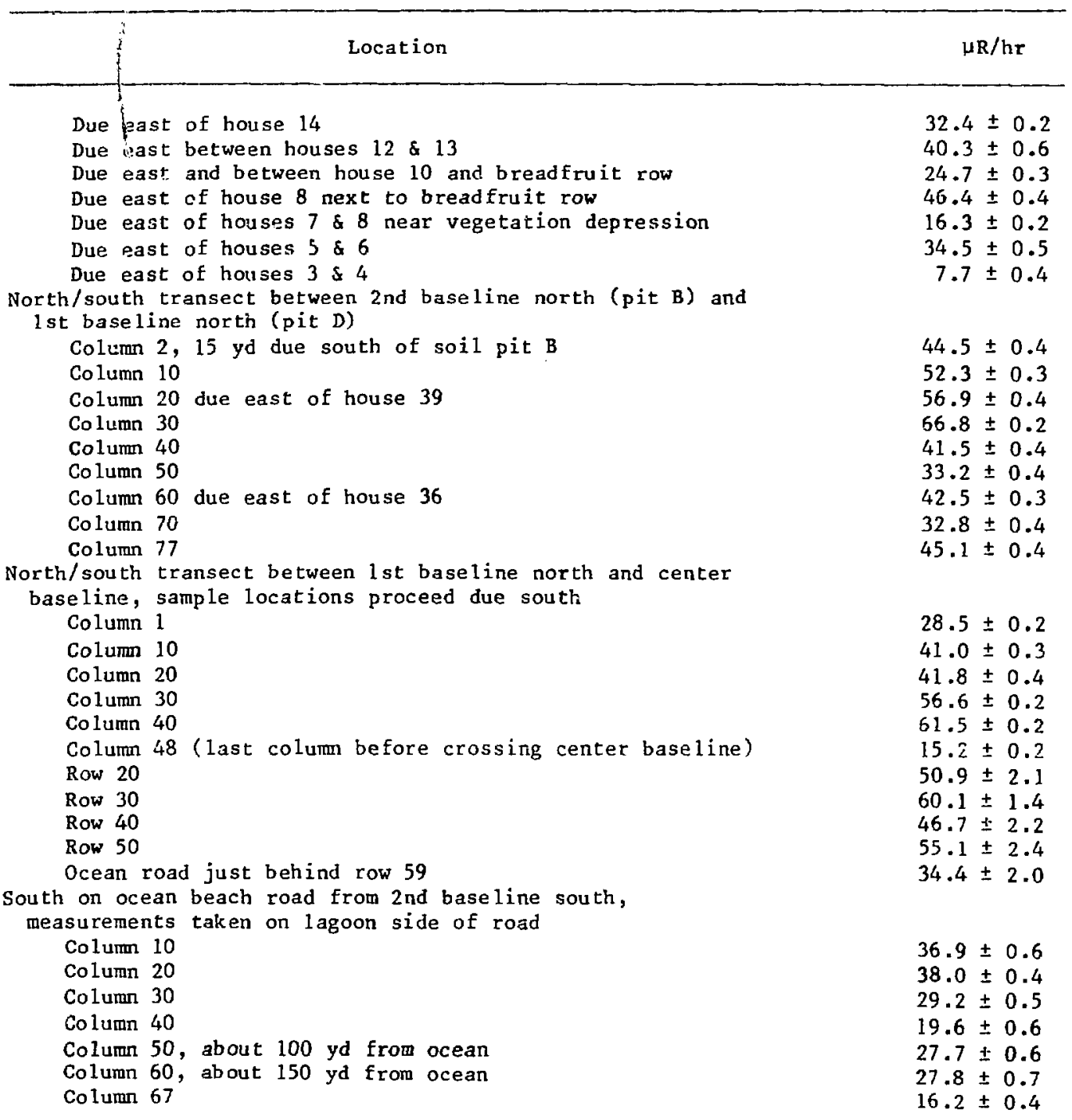


Table 5 (Cont'd)

Bikini Island RSS-111 Exposure Survey, Apri1 1975

Camp area

Bıldg. 1

B $1 \mathrm{dg}, 3$

Near church on northward bend of road halfway between equipment shed and house 1 (ocean side of road)

Lagocn road north, measurements taken on ocean side of road

Open area between houses 3 and 4

Open area between houses 5 and 6

open area between houses 7 and 8

Open area between houses 9 and 10

Open area between houses 12 and 13

Open area between houses 14 and 15

Open area between houses 16 and 17

Open area between houses 34 and 35

Open arez between houses 35 and 36

75 yd north of house 36

3rd baseline north starting at the lagoon road

Row 1

Row 5

Row 10

Lagoon road

$100 \mathrm{yd}$ south of north beach

Near house 40 - ocean side of road

Near hause 38 - lagoon side of road

50 yd south of house 37

Near house 35 - lagoon side

Village center - near intersection of lagoon road and center baseline

Soil pit $G$

Near house 25 - lagoon side

Near house 20 - lagoon side

Near house 15 - lagoon side

Near intersection of 1 st baseline and lagoon road

Near house 10 - lagoon side

$12.2 \pm 0.2$

$13.8 \pm 1.0$

$17.3 \pm 0.3$

$26.3 \pm 0.5$

$16.0 \pm 0.1$

$18.5 \pm 0.4$

$28.4 \pm 0.6$

$23.9 \pm 0.3$

$24.9 \pm 0.3$

$37.8 \pm 1.8$

$28.1 \pm 1.6$

$13.9 \pm 0.9$

$14.0 \pm 0.3$

$23.0 \pm 2.0$

Near house 5 - lagoon side

Near house 1 - lagoon side

$30.9 \pm 0.1$

$40.4 \pm 0.3$

$44.7 \pm 0.4$

$19.6 \pm 0.3$

$13.5 \pm 0.5$

$17.0 \pm 0.3$

$20.4: 0.4$

$31.6: 0.4$

$9.4: 0.4$

$22.5: 0.4$

$18.5: 0.1$

$18.2 \pm 0.2$

$24.7 \pm 0.2$

$17.5 \pm 0.2$

$26.0 \pm 0.3$

$11.8 \pm 0.1$

Second baseline south starting behind house 7

Behind house 7 , breadfruit row $\wedge 10$ yd to row 1

$27.0 \pm 0.9$

Row 10

Row 20

Row 30

$54.9 \pm 1.7$

$50.5 \pm 1.4$

$54.0 \pm 1.8$ 
Table 5 (Cont'd)

Bikini Island Res-11l Exposure Survey, April $1975^{*}$

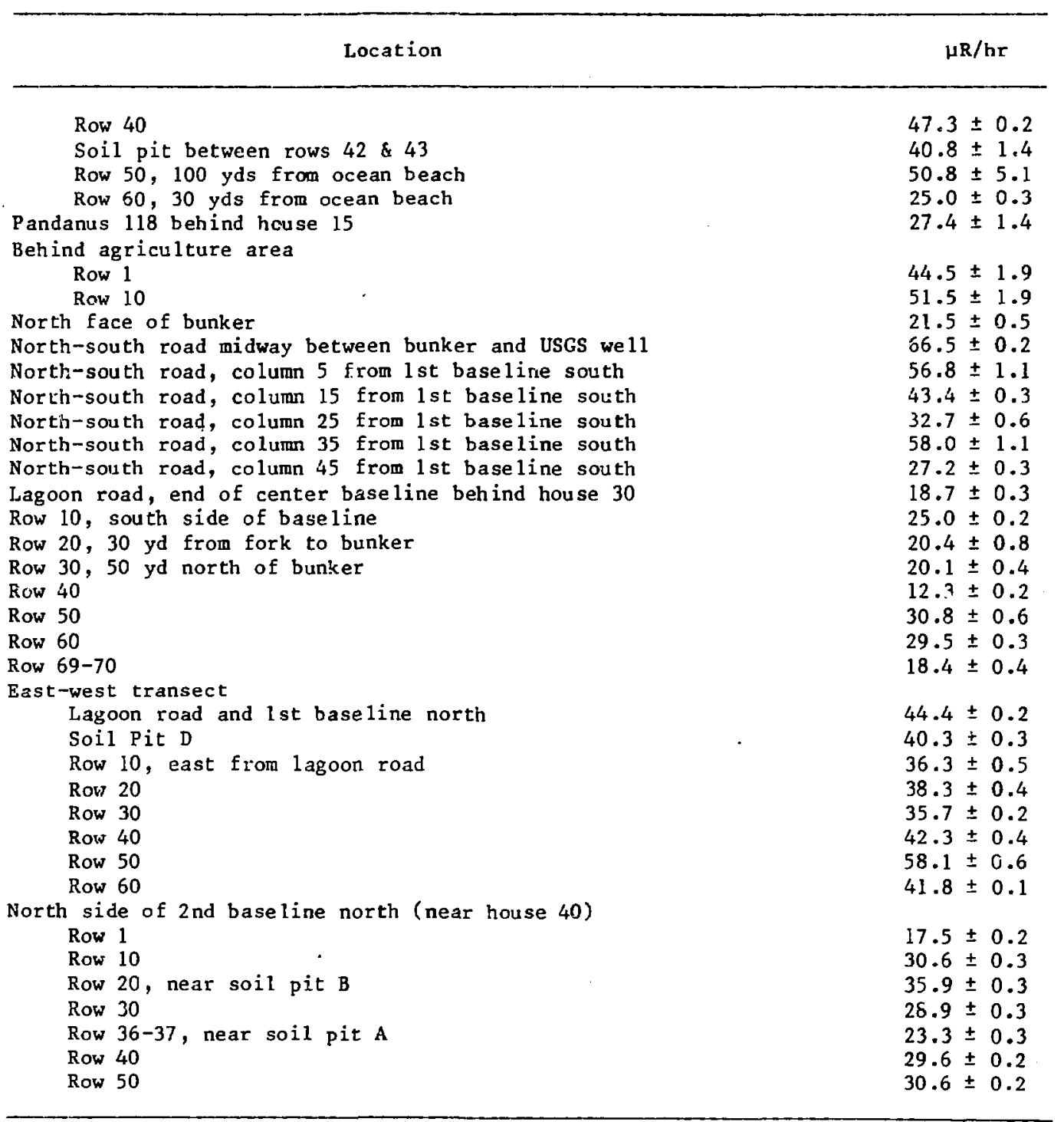


Tabie 6

Average Exposure Rate Corrected for Decay to May . 17

\begin{tabular}{lrrr} 
Island & No. of Observations & $\begin{array}{c}\text { Av. exposure rate } \\
\mu R / h r\end{array}$ \\
\hline Nam & 6 & $23.5 \pm 11.0$ & $5.7 \pm$ \\
Eneu & 21 & 32.1 & \pm 16.3 \\
Bikini & 203 & 1.1 & 16 \\
\hline
\end{tabular}

\section{Table 7}

Population Breakdown by Age and Geographical Living Patterns 5

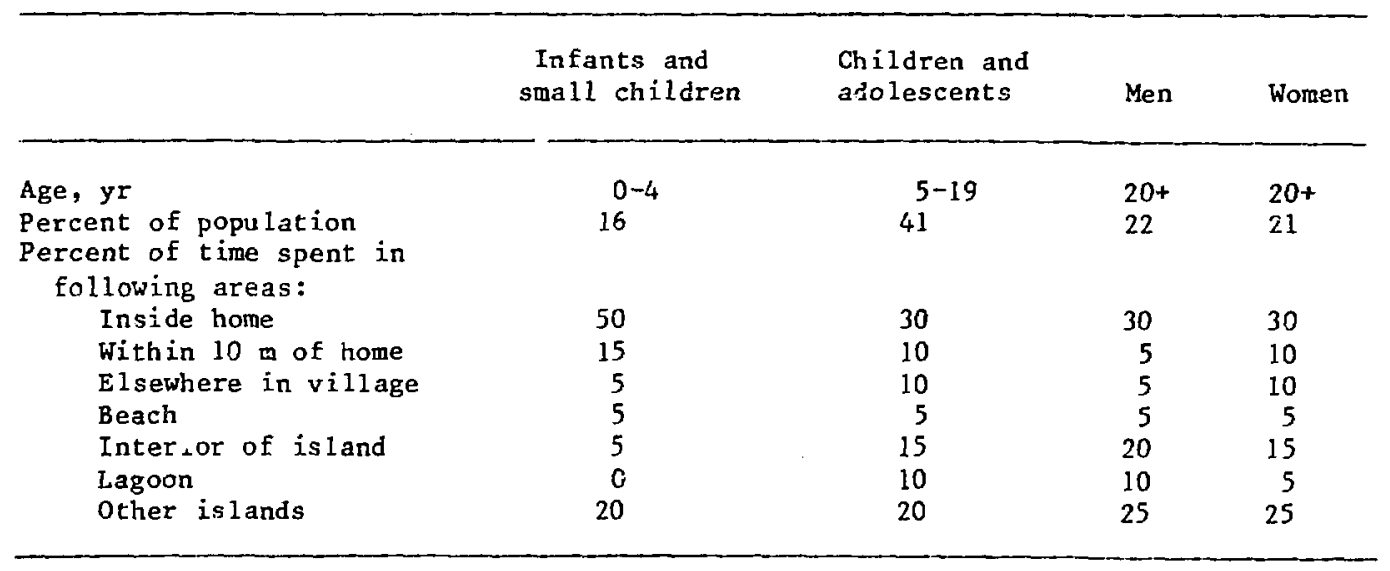


Table 8

Assumed Mean Exposure Rate for Each Activity Area

\begin{tabular}{lc}
\multicolumn{1}{c}{ Pattern } & $\begin{array}{c}\text { Bikini Atoll } \\
\mu R / h r\end{array}$ \\
& \\
Inside home & 9.7 \\
Within 10 th of home & 15.8 \\
Elsewhere in village & 25.3 \\
Beach & 15.8 \\
Interior island & 44.9 \\
Lagoon & $15.8^{*}$ \\
Other islands & $15.5^{*-*}$ \\
\hline
\end{tabular}

*Value assumed to be less than or equal to value for beach.

$* * B$ ased on assumption that equal amounts of time are spent on other islands within the Atoll.

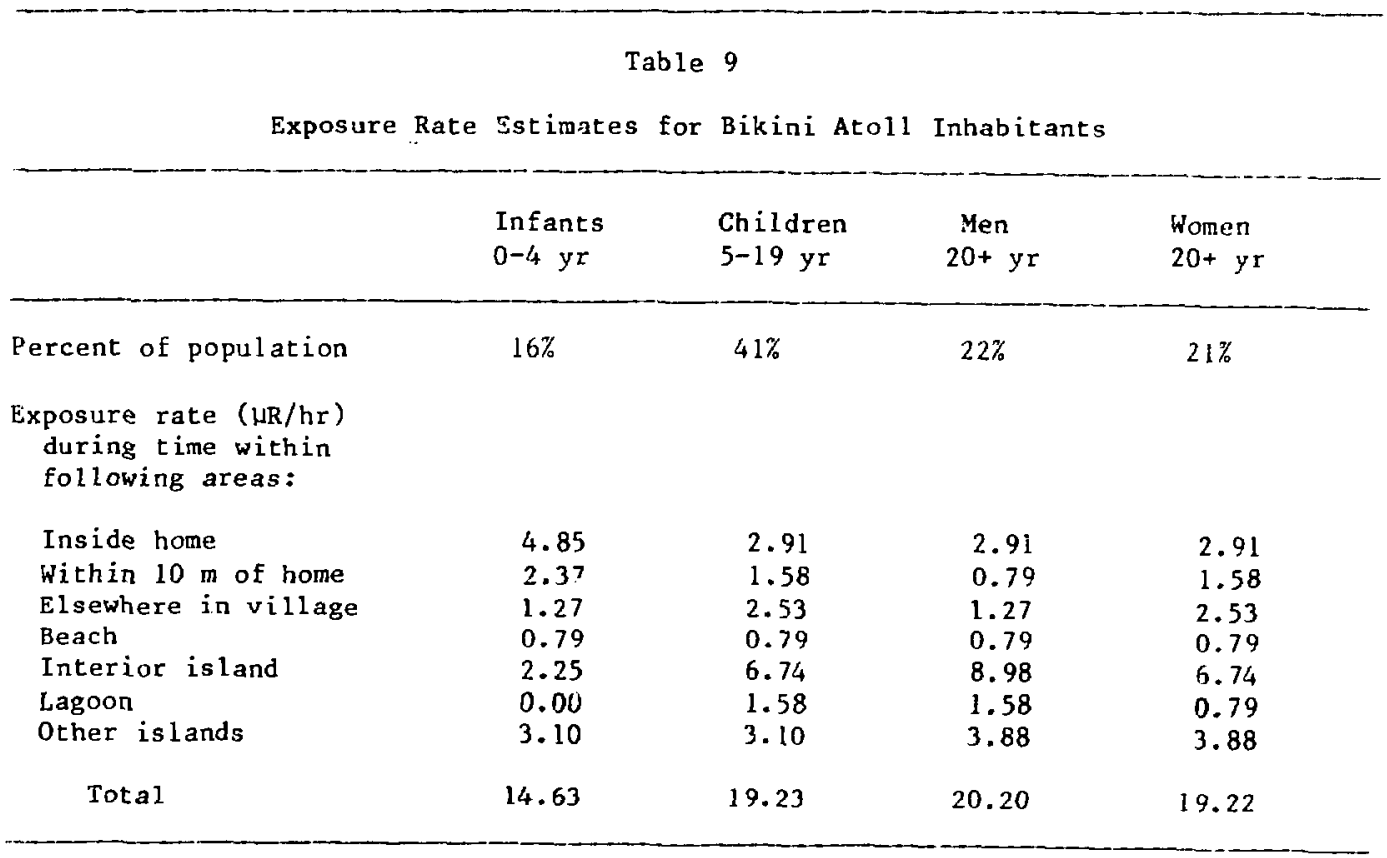


Table 10

External Dose Equivalent to Inhabitants of Bikini Atoll

\begin{tabular}{|c|c|c|c|c|}
\hline \multirow[b]{2}{*}{ Age Group } & \multirow{2}{*}{$\begin{array}{l}\text { Net ext. } \\
\text { exposure rate, } \\
\mu \mathrm{R} / \mathrm{hr} \text {, May } 77\end{array}$} & \multicolumn{3}{|c|}{$\begin{array}{c}\text { Ext. integrated dose equiv., rem } \\
\text { (background subtracted) }\end{array}$} \\
\hline & & $10 \mathrm{yr}$ & 30 yr & $50 \mathrm{yr}$ \\
\hline $\begin{array}{l}\text { Infants }(0-4) \\
\text { Children }(5-19) \\
\text { Men }(20+) \\
\text { Women }\left(20^{+}\right)\end{array}$ & $\begin{array}{l}10.27 \\
14.60 \\
15.52 \\
14.60\end{array}$ & $\begin{array}{l}0.80 \\
1.12 \\
1.20 \\
1.12\end{array}$ & $\begin{array}{l}1.90 \\
2.69 \\
2.85 \\
2.69\end{array}$ & $\begin{array}{l}2.59 \\
3.66 \\
3.88 \\
3.66\end{array}$ \\
\hline
\end{tabular}




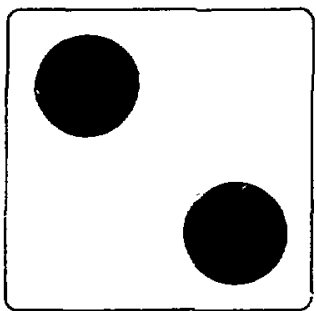

FRONT SIDE WITH $1.6 \mathrm{~cm}$ OUTER DIAMETER TAPPERED CUT-OUTS.

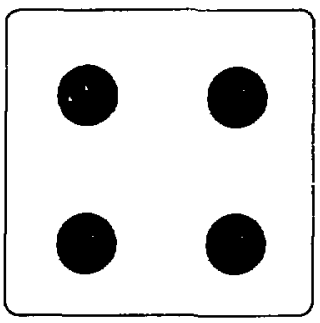

FRONT SIDE WITH I cm DIAMETER INSETS TO HOLD TLDS.

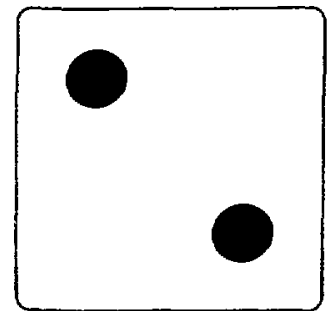

REAR SIDE WITH $1.1 \mathrm{~cm}$ INNER UIAMETER AND COVERED WITH A THIN LAYER OF MYLAR.

FRONT PANEL

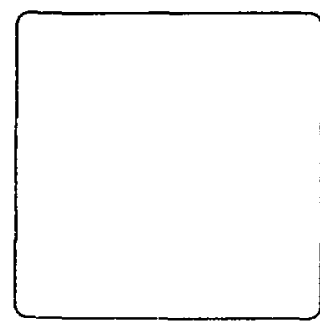

REAR SIDE, SOLID ALUMINUM.

REAR PANEL

Figure 1. Aluminum TLD holder. 


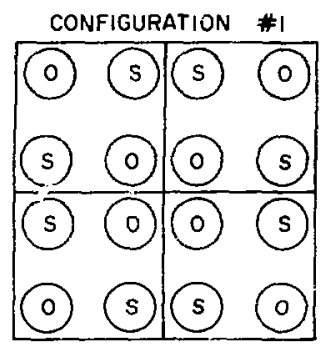

${ }^{90} \mathrm{Sr} / 9{ }^{90} \mathrm{Y}$ SOURCE PLACED 12 INCHES FROM THE MIDLINE OF THE TLD HOLDER.

$S$ - INDICATES TLD LOCATEd BENEATH $3.48 \mathrm{~mm}$ OF ALUMINUM

O - INDICATES TLD WASN'T SHIELdED

CALIBRATION FACTOR $=0.1458$ RADS/NANOCOULOMB

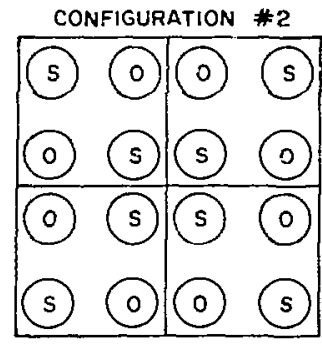

CALIBRATION FACTOR $=0.1414$ RADS $/$ NANOCOULOMB

CONFIGURATION \#3

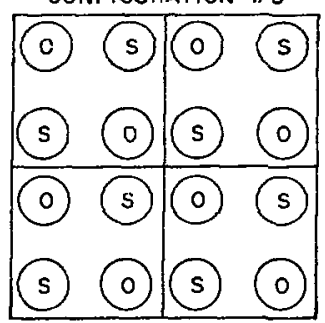

CALIBRATION FACTOR $=0.1464$ RADS/NANOCOULOMB

AVERAGE CALIBRATION FACTOR $=0.1445 \pm 0.00273$ RADS/NANOCOULOMB

Figure 2, Determination of Beta calibration factor. 


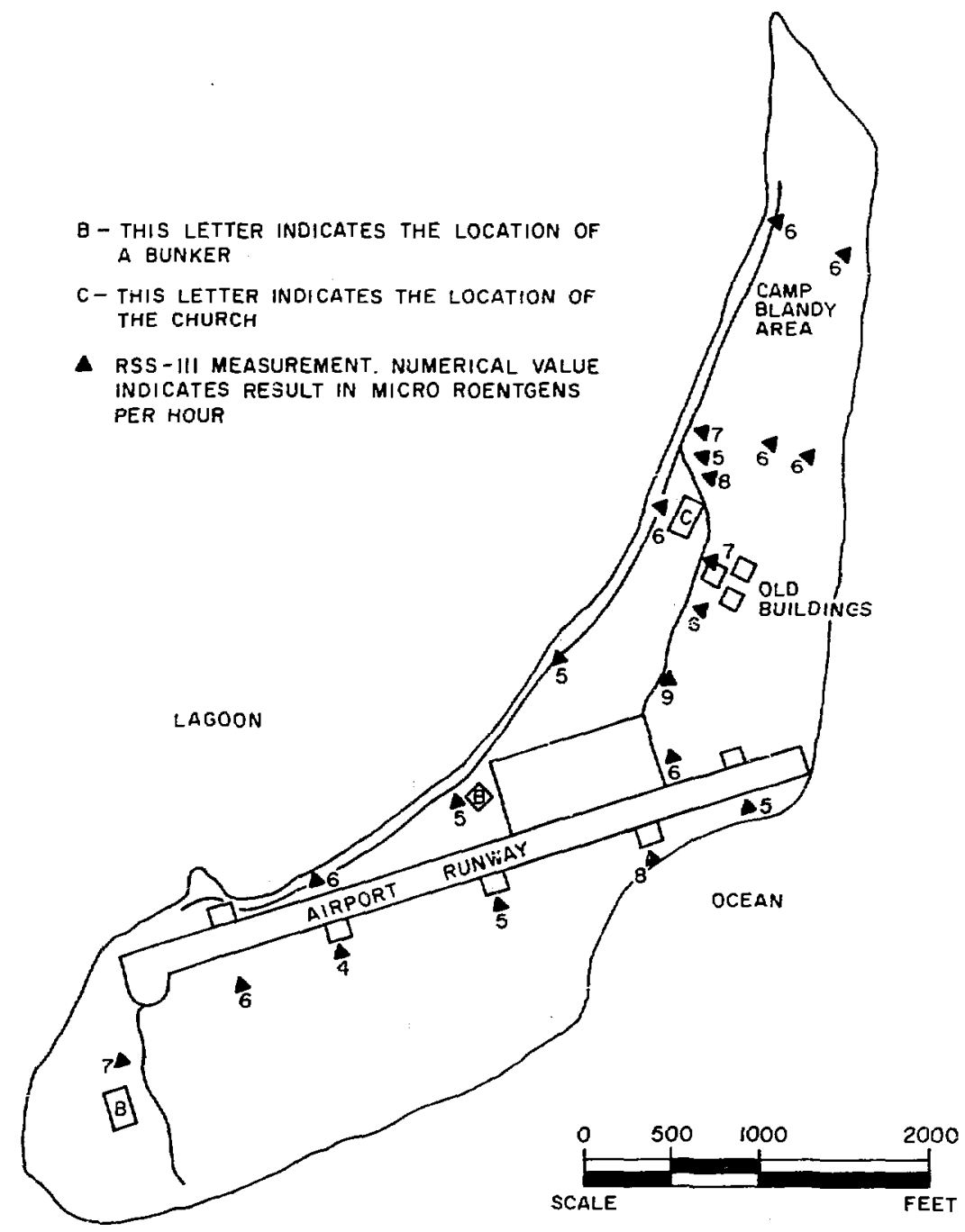

FIgure 3. Eneu Island external exposure survey, Apr11 1975. 


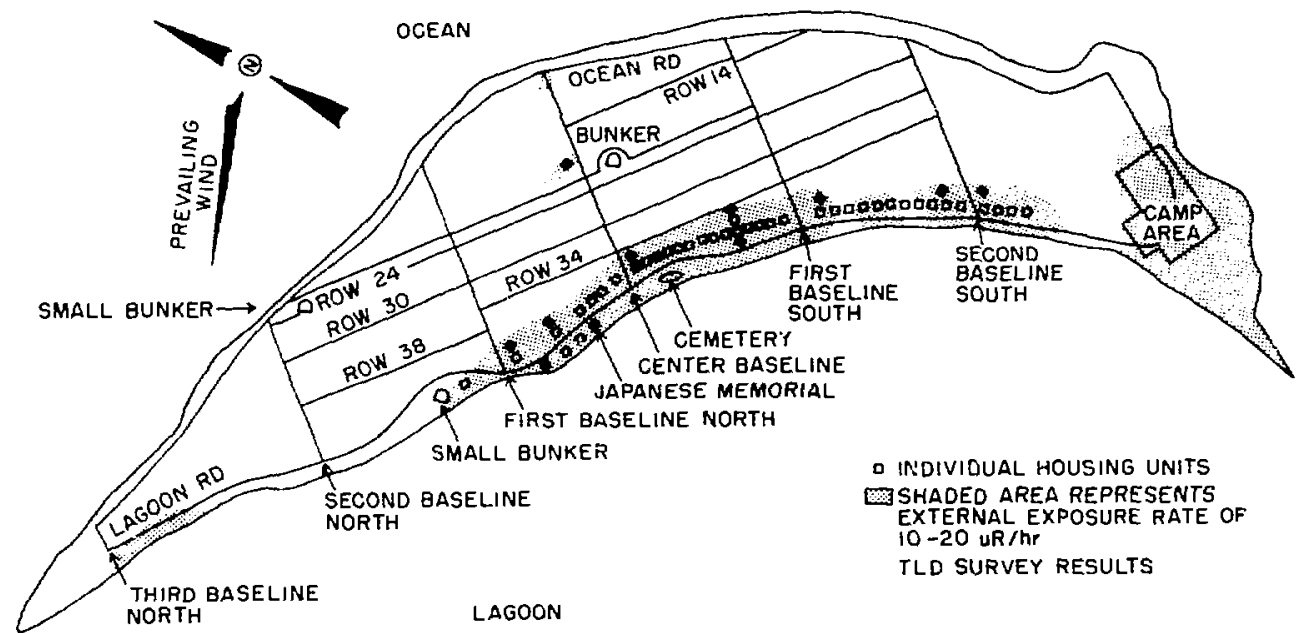

BIKINI ISLAND

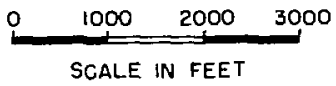

Figure 4A.

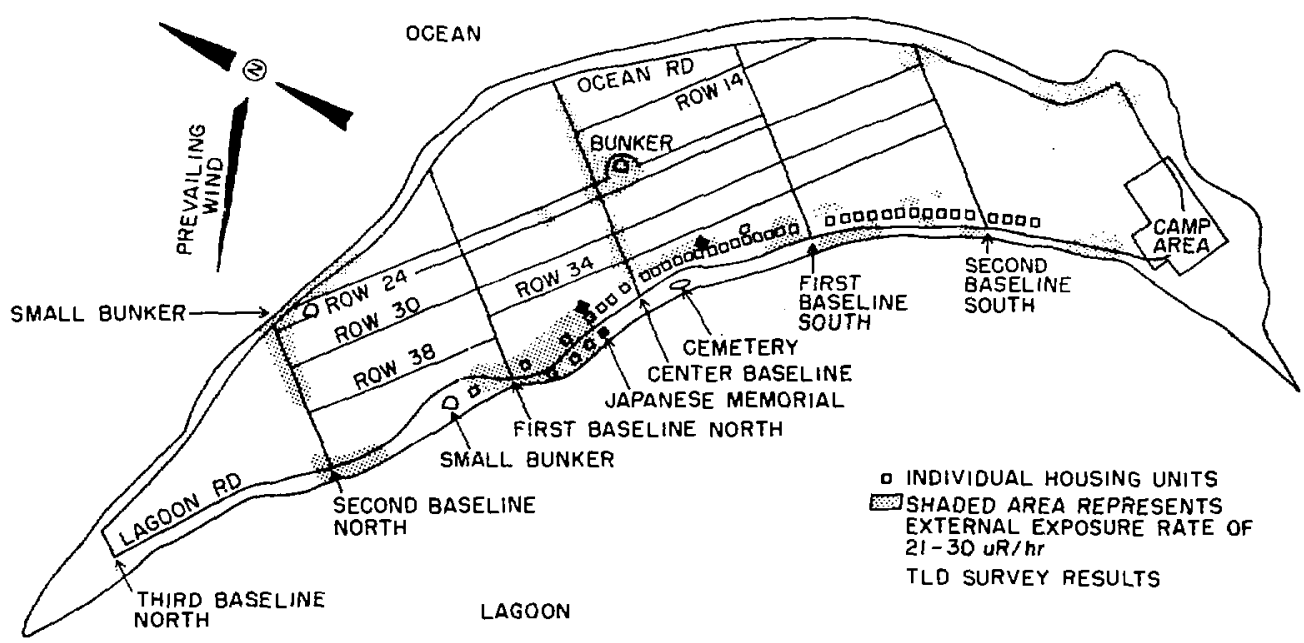

OIKINI ISLAND

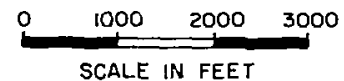

Eigure $4 B$. 


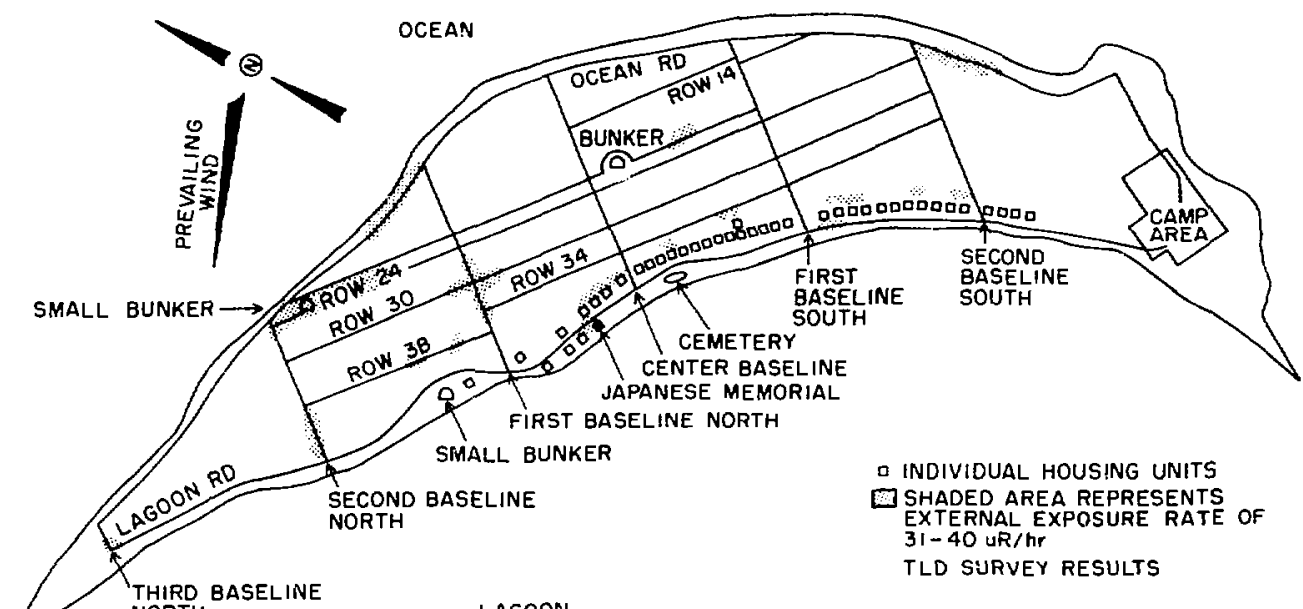

BIKINI ISLAND

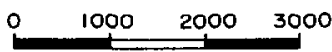

SCALE IN FEET

Figure $4 \mathrm{C}$.

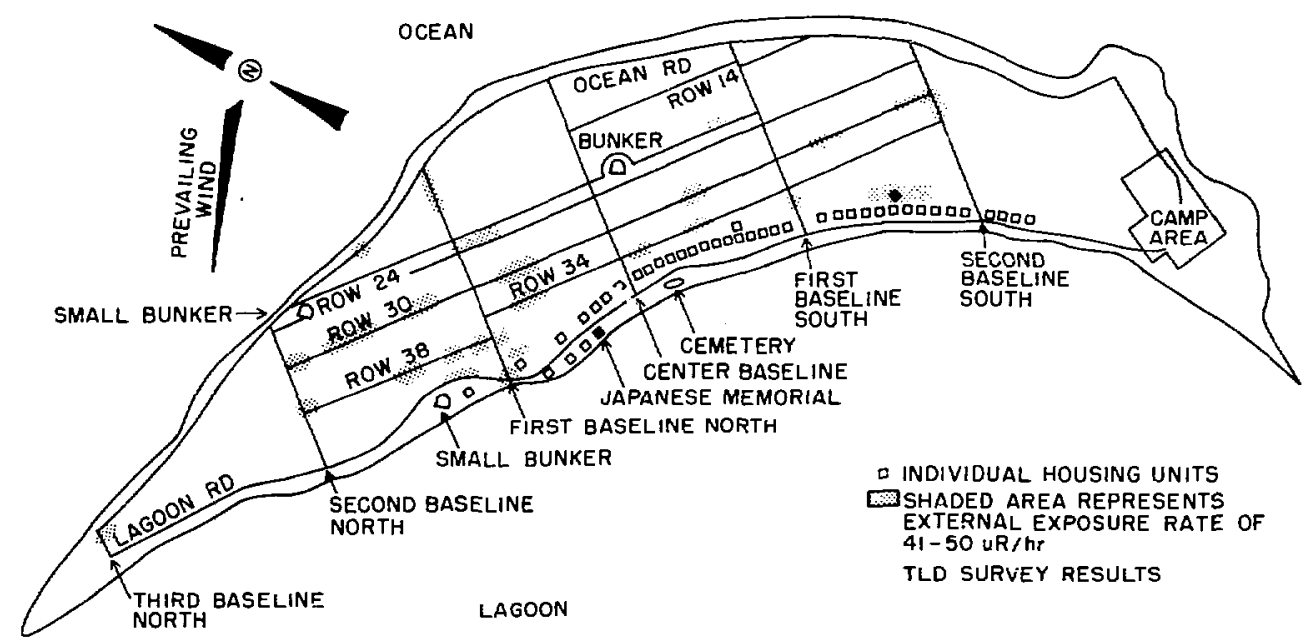

BIKINI ISLAND

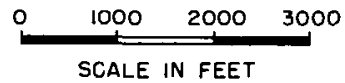

Figure 4D. 


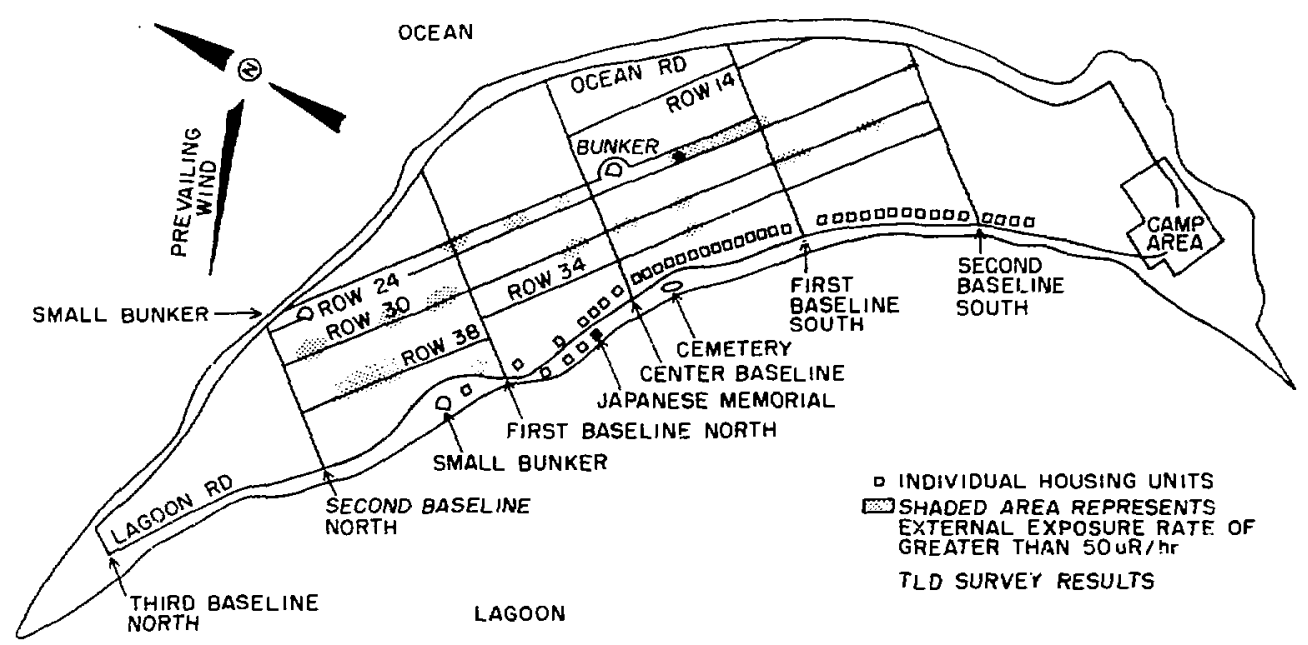

GIKINI ISLAND

$0 \quad 1000 \quad 2000 \quad 3000$

SCALE IN FEET

Figure 4E. 